\title{
Top-cited Articles in Primary Aldosteronism: A Bibliometric Analysis
}

\author{
Qiang-Hong Pu ${ }^{1}$, Qiu-Ju Lyu ${ }^{2, *}$ \\ ${ }^{1}$ Department of Pharmacy, People's Hospital of Leshan, Leshan, China \\ ${ }^{2}$ Department of Endocrinology, People's Hospital of Leshan, Leshan, China
}

Email address:

22641201@qq.com (Qiu-Ju Lyu)

*Corresponding author

\section{To cite this article:}

Qiang-Hong Pu, Qiu-Ju Lyu. Top-cited Articles in Primary Aldosteronism: A Bibliometric Analysis. International Journal of Diabetes and Endocrinology. Vol. 6, No. 3, 2021, pp. 95-104. doi: 10.11648/j.ijde.20210603.12

Received: July 7, 2021; Accepted: July 26, 2021; Published: August 4, 2021

\begin{abstract}
Background: The objective of this study was to identify the top 100 cited articles in primary aldosteronism, and examine their characteristics. Methods: Science Citation Index Expanded database was utilized to search for the top 100 cited articles published since 1900. Articles were evaluated for several characteristics, including the number of citations, authorship, country and institution of origin, publication year, journal, and study design. Results: The top 100 articles were cited between 88 and 762 times, with a median of 130. The articles were published between 1955 and 2012, with the majority of the primary aldosteronism publications $(n=35)$ being published between 2000 and 2009. The biggest number of the top 100 cited articles $(\mathrm{n}=19)$ were published in the Journal of Clinical Endocrinology Metabolism, followed by Hypertension ( $\mathrm{n}=9)$, Annals of Internal Medicine $(\mathrm{n}=6)$, and Archives of Internal Medicine $(\mathrm{n}=6)$. The United States and Italy had the most publications, whereas University of Michigan and University of Padua were the top two institutions. Observational studies were the most popular article type, followed by reviews and basic science. The impact factor of a journal was not correlated with the number of top-cited articles it published. Furthermore there was no correlation between the number of citations and the number of years since publication, authors, participating institutions, or countries involved. Conclusion: These findings will assist researchers in quickly identifying the most significant advances in the field of primary aldosteronism, as well as deciphering the characteristics of top-cited articles in this subject, and laying a basis for further research.
\end{abstract}

Keywords: Bibliometrics, Primary Aldosteronism, Citation Classics, Citation Analysis

\section{Introduction}

Primary aldosteronism syndrome is characterized by hypertension and is caused by the autonomous secretion of aldosterone from adrenocortical lesions. Primary aldosteronism is found in over $10 \%$ of hypertensive patients and is the most frequent cause of secondary hypertension [1]. Besides, it is associated with hypokalemia, renal insufficiency, and cardiovascular diseases such as coronary artery disease, stroke, myocardial infarction, cardiomegaly, arrhythmia, among others [2, 3]. Numerous articles on primary aldosteronism have been published in the past decades, and the number continues to grow. Therefore, it is challenging for a medical researcher or clinician to obtain a general understanding of primary aldosteronism due to the abundance of articles. Classic papers (also known as top-cited articles) promote the development of any field of research. Consequently, there is an urgent need to assist researchers and clinicians in locating classic articles in the field of primary aldosteronism. However, identifying the classic papers on primary aldosteronism has received little attention.

Although the value of citation rate has been questioned, it has been widely used to assess the impact of a research article and identify major discoveries and challenges in a specific medical field [4]. The citation rate is a bibliometric analysis that investigates the frequency and pattern of citations of an article. The number of citations that an article receives is an important metric for assessing its impact in the scientific community [5]. The more citations an article has, the more valuable it is in its field. Recently, the top-cited articles were identified and analyzed in various medical fields, such as 
urology, respiratory diseases, pain, hypospadiology, tuberculosis, hypertension, diabetes, orthodontics, digestive diseases, and dermatology [6-15]. However, similar identification and analyses in primary aldosteronism have yet to be performed. Therefore, this study aimed at identifying the top 100 cited articles in primary aldosteronism, and examine their characteristics using a bibliometric analysis.

\section{Methods}

There was no need for ethical approval because no patients were enrolled in this study. However, the study was conducted in accordance to the Preferred Reporting Items for Systematic Reviews and Meta-analysis (PRISMA) guidelines [16].

\subsection{Study Design and Data Search}

Science Citation Index Expanded (SCIE, 1900-2016) database was used to identify the top 100 cited articles in primary aldosteronism research. The following search terms were used: "Conns syndrome*" OR "Conn syndrome*" OR "Conn's syndrome*" OR hyperaldosteronism* OR aldosteronism* OR "primary adrenal hyperplasia*" OR "aldosterone-producing adenoma*" OR "aldosterone-producing carcinoma*" OR aldosteronoma*. The asterisk (*) was used as a wild card character in the search string. Results presented in this study were based on data collected over the internet on April 18, 2016. No language was restricted in this search.

\subsection{Inclusion and Exclusion Criteria}

The inclusion criteria were as follow: (1) papers focusing on primary aldosteronism as the main topic; (2) original articles and reviews. The following were the exclusion criteria: (1) articles focused on broad areas, with no emphasis on primary aldosteronism; (2) meeting abstracts, letters, editorial materials, corrections, book chapters, errata, discussions, or book reviews.

\subsection{Identification and Assessment of the Top 100 Articles}

The search results were ranked in descending order using the option "times cited". Two independent researchers reviewed the findings, to ensure that the articles focused on primary aldosteronism research, and determined the top 100 cited articles. Clinical studies on primary aldosteronism were included. However, articles that focused on secondary aldosteronism, hypertension, Cushing's syndrome, hypokalemia, and heart failure were excluded. Subsequently, two investigators re-examined the top 100 cited articles, and all researchers extracted data including number of citations, citation density, authorship (only considering the first author), number of authors, country and institution of origin, publication year, name of the journal, and study design.

Articles were grouped into six different categories according to study design and goal: (1) randomized controlled trial (RCT); (2) observational study including cohort studies, case-control studies, cross-sectional studies and case series; (3) basic science including bench-top laboratory research and research involving animal or cell models; (4) review; (5) meta-analysis or systematic review; (6) clinical guidelines. Additionally, the Oxford Centre for Evidence-based Medicine - Levels of Evidence (2009 edition) was chosen to assess the top-cited articles. Once a list of journal impact factors was obtained from the Journal Citation Report 2015, we studied the correlation between each journal's impact factor and the number of top 100 articles it published. Lastly, we investigated the correlation between the number of citations and other characteristics, including the number of years since publication, the number of authors, participating countries, and institutions involved.

\subsection{Statistical Analyses}

All data were analyzed using GraphPad Prism software (Version 6, GraphPad Software Inc. CA USA). Correlations were determined using nonparametric Spearman rank. All statistical tests were two-tailed and $P<0.05$ was considered statistically significant.

\section{Results}

\subsection{Citations}

Table 1 shows the characteristics of the top 100 cited articles in primary aldosteronism research in descending order of total citations. The median number of citations for the top 100 articles was 130 (ranging from 88 to 762). The total number of citations in SCIE was positively correlated with citation density $(\mathrm{r}=0.52, P<0.05)$. The most cited article (762 citations) studied genomic mutations in aldosterone synthase (11 beta-hydroxylase), which caused the main subtype of primary aldosteronism: glucocorticoid-remediable aldosteronism, published in 1992 by Lifton RP et al in Nature [17]. A guideline on detection, diagnosis, and treatment of primary aldosteronism, published in 2008 by Funder JW et al in Journal of Clinical Endocrinology \& Metabolism, was the second most cited article (682 citations) but had the highest citation-density [1]. The third most cited study (624 citations) was a classic report on primary aldosteronism as a new clinical syndrome, published in 1955 by Conn JW et al in Journal of Laboratory and Clinical Medicine [18].

Table 1. The top 100 cited articles in primary aldosteronism research.

\begin{tabular}{|c|c|c|c|c|}
\hline rank & article & study design & citations & $\begin{array}{l}\text { citation } \\
\text { density }\end{array}$ \\
\hline 1 & $\begin{array}{l}\text { Lifton RP, et al. A chimeric 11-beta-hydroxylase aldosterone synthase gene causes } \\
\text { glucocorticoid-remediable aldosteronism and human hypertension. Nature. 1992; } 355 \text { (6357): 262-265 }\end{array}$ & basic science & 762 & 32 \\
\hline 2 & $\begin{array}{l}\text { Funder JW, et al. Case detection, diagnosis, and treatment of patients with primary aldosteronism: an } \\
\text { endocrine society clinical practice guideline. Journal of Clinical Endocrinology \& Metabolism. 2008; }\end{array}$ & guideline & 682 & 85 \\
\hline
\end{tabular}




\begin{tabular}{|c|c|c|c|c|}
\hline rank & article & study design & citations & $\begin{array}{l}\text { citation } \\
\text { density }\end{array}$ \\
\hline & 93 (9): 3266-3281 & & & \\
\hline 3 & $\begin{array}{l}\text { Conn JW, et al. Presidential address. I. Painting background. Ii. Primary aldosteronism, a new clinical } \\
\text { syndrome.. Journal of Laboratory and Clinical Medicine. 1955; } 45 \text { (1): 3-17 }\end{array}$ & observational study & 624 & 10 \\
\hline 4 & $\begin{array}{l}\text { Milliez P, et al. Evidence for an increased rate of cardiovascular events in patients with primary } \\
\text { aldosteronism. Journal of the American College of Cardiology. 2005; } 45 \text { (8): 1243-1248 }\end{array}$ & observational study & 543 & 49 \\
\hline 5 & $\begin{array}{l}\text { Rossi GP, et al. A prospective study of the prevalence of primary aldosteronism in 1,125 hypertensive } \\
\text { patients. Journal of the American College of Cardiology. 2006; } 48 \text { (11): 2293-2300 }\end{array}$ & observational study & 423 & 42 \\
\hline 6 & $\begin{array}{l}\text { Conn JW, et al. Clinical characteristics of primary aldosteronism from an analysis of } 145 \text { cases. } \\
\text { American Journal of Surgery. 1964; } 107 \text { (1): 159-172 }\end{array}$ & review & 393 & 8 \\
\hline 7 & $\begin{array}{l}\text { Conn JW, et al. Suppression of plasma renin activity in primary aldosteronism - distinguishing primary } \\
\text { from secondary aldosteronism in hypertensive disease. JAMA. 1964; } 190 \text { (3): 213-221 }\end{array}$ & observational study & 361 & 7 \\
\hline 8 & $\begin{array}{l}\text { Gordon RD, et al. High-incidence of primary aldosteronism in } 199 \text { patients referred with hypertension. } \\
\text { Clinical and Experimental Pharmacology and Physiology. 1994; } 21 \text { (4): } 315-318\end{array}$ & observational study & 301 & 14 \\
\hline 9 & $\begin{array}{l}\text { Weinberger MH, et al. Primary aldosteronism - diagnosis, localization, and treatment. Annals of } \\
\text { Internal Medicine. 1979; } 90 \text { (3): 386-395 }\end{array}$ & review & 300 & 8 \\
\hline 10 & $\begin{array}{l}\text { Calhoun DA, et al. Hyperaldosteronism among with resistant black and white subjects hypertension. } \\
\text { Hypertension. 2002; } 40 \text { (6): 892-896 }\end{array}$ & observational study & 295 & 21 \\
\hline 11 & $\begin{array}{l}\text { Choi M, et al. K+ channel mutations in adrenal aldosterone-producing adenomas and hereditary } \\
\text { hypertension. Science. } 2011 ; 331 \text { (6018): 768-772 }\end{array}$ & basic science & 276 & 55 \\
\hline 12 & $\begin{array}{l}\text { Fardella CE, et al. Primary hyperaldosteronism in essential hypertensives: prevalence, biochemical profile, } \\
\text { and molecular biology. Journal of Clinical Endocrinology \& Metabolism. 2000; } 85 \text { (5): 1863-1867 }\end{array}$ & observational study & 276 & 17 \\
\hline 13 & $\begin{array}{l}\text { Hiramatsu K, et al. A screening-test to identify aldosterone-producing adenoma by measuring plasma-renin } \\
\text { activity - results in hypertensive patients. Archives of Internal Medicine. 1981; } 141 \text { (12): 1589-1593 }\end{array}$ & observational study & 276 & 8 \\
\hline 14 & $\begin{array}{l}\text { Bravo EL, et al. The changing clinical spectrum of primary aldosteronism. American Journal of } \\
\text { Medicine. 1983; } 74 \text { (4): 641-651 }\end{array}$ & observational study & 239 & 7 \\
\hline 15 & $\begin{array}{l}\text { Melby JC, et al. Diagnosis and localization of aldosterone-producing adenomas by adrenal-vein } \\
\text { catheterization. New England Journal of Medicine. 1967; } 277 \text { (20): 1050-1056 }\end{array}$ & observational study & 239 & 5 \\
\hline 16 & $\begin{array}{l}\text { Young WF, et al. Role for adrenal venous sampling in primary aldosteronism. Surgery. 2004; } 136 \text { (6): } \\
1227-1233\end{array}$ & observational study & 235 & 20 \\
\hline 17 & Conn JW. Primary aldosteronism. Journal of Laboratory and Clinical Medicine. 1955; 45 (4): 661-664 & observational study & 234 & 4 \\
\hline 18 & $\begin{array}{l}\text { Young WF. Normokalemic primary aldosteronism - a detectable cause of curable essential } \\
\text { hypertension. JAMA. 1965; } 193 \text { (3): 200-206 }\end{array}$ & observational study & 233 & 5 \\
\hline 19 & $\begin{array}{l}\text { Loh KC, et al. Primary aldosteronism: renaissance of a syndrome. Clinical Endocrinology. 2007; } 66 \\
\text { (5): } 607-618\end{array}$ & review & 222 & 25 \\
\hline 20 & $\begin{array}{l}\text { Mosso L, et al. Prevalence of primary aldosteronism among asian hypertensive patients in singapore. } \\
\text { Journal of Clinical Endocrinology \& Metabolism. 2000; } 85 \text { (8): 2854-2859 }\end{array}$ & observational study & 214 & 13 \\
\hline 21 & $\begin{array}{l}\text { Ganguly A, et al. Primary aldosteronism and hypertensive disease. Hypertension. } 2003 ; 42 \text { (2): } \\
\text { 161-165 }\end{array}$ & observational study & 207 & 16 \\
\hline 22 & $\begin{array}{l}\text { Mulatero P, et al. Control of plasma aldosterone in primary aldosteronism: distinction between } \\
\text { adenoma and hyperplasia. Journal of Clinical Endocrinology \& Metabolism. 1973; } 37 \text { (5): 765-775 }\end{array}$ & observational study & 194 & 5 \\
\hline 23 & $\begin{array}{l}\text { Ganguly A, et al. Drug effects on aldosterone/plasma renin activity ratio in primary aldosteronism. } \\
\text { Hypertension. } 2002 ; 40(6): 897-902\end{array}$ & $\begin{array}{l}\text { randomized } \\
\text { controlled trial }\end{array}$ & 193 & 14 \\
\hline 24 & $\begin{array}{l}\text { Rossi GP, et al. Current concepts - primary aldosteronism. New England Journal of Medicine. 1998; } \\
339 \text { (25): 1828-1834 }\end{array}$ & review & 191 & 11 \\
\hline 25 & $\begin{array}{l}\text { Conn JW. Renal damage in primary aldosteronism - results of the papy study. Hypertension. 2006; } 48 \\
\text { (2): } 232-238\end{array}$ & observational study & 189 & 19 \\
\hline 26 & $\begin{array}{l}\text { Pascoe L, et al. Plasma renin activity in primary aldosteronism - importance in differential diagnosis }+ \\
\text { in research of essential hypertension. JAMA. } 1964 ; 190 \text { (3): } 222-225\end{array}$ & review & 188 & 4 \\
\hline 27 & $\begin{array}{l}\text { Young WF. Glucocorticoid-suppressible hyperaldosteronism results from hybrid genes created by } \\
\text { unequal crossovers between cyp11b1 and cyp11b2. PNAS. 1992; } 89 \text { (17): 8327-8331 }\end{array}$ & basic science & 182 & 8 \\
\hline 28 & $\begin{array}{l}\text { Blumenfeld JD, et al. Minireview: primary aldosteronism - changing concepts in diagnosis and } \\
\text { treatment. Endocrinology. 2003; } 144 \text { (6): } 2208-2213\end{array}$ & review & 181 & 14 \\
\hline 29 & $\begin{array}{l}\text { Lim PO, et al. Diagnosis and treatment of primary hyperaldosteronism. Annals of Internal Medicine. } \\
1994 ; 121 \text { (11): 877-885 }\end{array}$ & observational study & 181 & 8 \\
\hline 30 & $\begin{array}{l}\text { Streeten DHP, et al. High prevalence of primary aldosteronism in the tayside hypertension clinic } \\
\text { population. Journal of Human Hypertension. 2000; } 14(5): 311-315\end{array}$ & observational study & 166 & 10 \\
\hline 31 & $\begin{array}{l}\text { Rossi GP, et al. Reliability of screening methods for the diagnosis of primary aldosteronism. American } \\
\text { Journal of Medicine. 1979; } 67 \text { (3): 403-413 }\end{array}$ & observational study & 164 & 4 \\
\hline 32 & $\begin{array}{l}\text { Gallay BJ, et al. Remodeling of the left ventricle in primary aldosteronism due to conn's adenoma. } \\
\text { Circulation. 1997; } 95 \text { (6): 1471-1478 }\end{array}$ & observational study & 161 & 8 \\
\hline 33 & $\begin{array}{l}\text { Newton MA, et al. Screening for primary aldosteronism without discontinuing hypertensive } \\
\text { medications: plasma aldosterone-renin ratio. American Journal of Kidney Diseases. 2001; } 37 \text { (4): } \\
699-705\end{array}$ & observational study & 159 & 11 \\
\hline 34 & $\begin{array}{l}\text { Rossi GP, et al. Effect of corticotropin on aldosterone excretion and plasma renin in normal subjects in } \\
\text { essential hypertension and in primary aldosteronism. Journal of Clinical Endocrinology \& Metabolism. } \\
\text { 1968; } 28 \text { (7): 1006-1013 }\end{array}$ & observational study & 158 & 3 \\
\hline
\end{tabular}




\begin{tabular}{|c|c|c|c|c|}
\hline rank & article & study design & citations & $\begin{array}{l}\text { citation } \\
\text { density }\end{array}$ \\
\hline 35 & $\begin{array}{l}\text { Rossi GP, et al. Identification of the etiology of primary aldosteronism with adrenal vein sampling in } \\
\text { patients with equivocal computed tomography and magnetic resonance findings: results in } 104 \\
\text { consecutive cases. Journal of Clinical Endocrinology \& Metabolism. 2001; 86 (3): 1083-1090 }\end{array}$ & observational study & 157 & 10 \\
\hline 36 & $\begin{array}{l}\text { Young WF, et al. Changes in left ventricular anatomy and function in hypertension and primary } \\
\text { aldosteronism. Hypertension. 1996; } 27 \text { (5): 1039-1045 }\end{array}$ & observational study & 156 & 8 \\
\hline 37 & $\begin{array}{l}\text { Conn JW, et al. Primary aldosteronism - diagnosis and treatment. Mayo Clinic Proceedings. 1990; } 65 \\
\text { (1): 96-110 }\end{array}$ & review & 154 & 6 \\
\hline 38 & $\begin{array}{l}\text { Stowasser M, et al. Primary aldosteronism, a new clinical entity. Annals of Internal Medicine. 1956; } 44 \\
\text { (1): 1-15 }\end{array}$ & observational study & 154 & 3 \\
\hline 39 & $\begin{array}{l}\text { Sawka AM, et al. High rate of detection of primary aldosteronism, including surgically treatable forms, } \\
\text { after 'non-selective' screening of hypertensive patients. Journal of Hypertension. 2003; } 21 \text { (11): } \\
2149-2157\end{array}$ & observational study & 152 & 12 \\
\hline 40 & $\begin{array}{l}\text { Fallo F, et al. Primary aldosteronism: factors associated with normalization of blood pressure after } \\
\text { surgery. Annals of Internal Medicine. } 2001 ; 135 \text { (4): } 258-261\end{array}$ & observational study & 151 & 10 \\
\hline 41 & $\begin{array}{l}\text { Magill SB, et al. Prevalence and characteristics of the metabolic syndrome in primary aldosteronism. } \\
\text { Journal of Clinical Endocrinology \& Metabolism. 2006; } 91 \text { (2): 454-459 }\end{array}$ & observational study & 150 & 15 \\
\hline 42 & $\begin{array}{l}\text { Conn JW, et al. Comparison of adrenal vein sampling and computed tomography in the differentiation } \\
\text { of primary aldosteronism. Journal of Clinical Endocrinology \& Metabolism. 2001; } 86 \text { (3): 1066-1071 }\end{array}$ & observational study & 149 & 10 \\
\hline 43 & $\begin{array}{l}\text { Sechi LA, et al. Primary aldosteronism - photoscanning of tumors after administration of } \\
\text { i-131-19-iodocholesterol. Archives of Internal Medicine. 1972; } 129(3): 417-425\end{array}$ & observational study & 145 & 3 \\
\hline 44 & $\begin{array}{l}\text { Gordon RD, et al. Long-term renal outcomes in patients with primary aldosteronism. JAMA. 2006; } 295 \\
\text { (22): 2638-2645 }\end{array}$ & observational study & 144 & 14 \\
\hline 45 & $\begin{array}{l}\text { Lim PO, et al. Evidence that primary aldosteronism may not be uncommon - 12-percent incidence } \\
\text { among antihypertensive drug trial volunteers. Clinical and Experimental Pharmacology and } \\
\text { Physiology. 1993; } 20 \text { (5): 296-298 }\end{array}$ & observational study & 144 & 6 \\
\hline 46 & $\begin{array}{l}\text { Kawamoto T, et al. Potentially high prevalence of primary aldosteronism in a primary-care population. } \\
\text { Lancet. 1999; } 353 \text { (9146): } 40\end{array}$ & observational study & 143 & 8 \\
\hline 47 & $\begin{array}{l}\text { Douma S, et al. Cloning and expression of a cdna for human cytochrome-p-450aldo as related to primary } \\
\text { aldosteronism. Biochemical and Biophysical Research Communications. 1990; } 173 \text { (1):309-316 }\end{array}$ & basic science & 143 & 6 \\
\hline 48 & $\begin{array}{l}\text { Milne MD, et al. Prevalence of primary hyperaldosteronism in resistant hypertension: a retrospective } \\
\text { observational study. Lancet. 2008; } 371 \text { (9628): 1921-1926 }\end{array}$ & observational study & 142 & 18 \\
\hline 49 & Dunn PJ, et al. Primary aldosteronism. Quarterly Journal of Medicine. 1957; 26 (103): 317-33 & observational study & 138 & 2 \\
\hline 50 & $\begin{array}{l}\text { Catena C, et al. Outpatient screening-tests for primary aldosteronism. Australian and New Zealand } \\
\text { Journal of Medicine. 1976; } 6 \text { (2): 131-135 }\end{array}$ & observational study & 132 & 3 \\
\hline 51 & $\begin{array}{l}\text { Fishman LM, et al. Long-term cardiac effects of adrenalectomy or mineralocorticoid antagonists in } \\
\text { patients with primary aldosteronism. Hypertension. 2007; } 50 \text { (5): } 911-918\end{array}$ & observational study & 127 & 14 \\
\hline 52 & $\begin{array}{l}\text { Rich GM, et al. Incidence of primary aldosteronism uncomplicated essential hypertension - a } \\
\text { prospective study with elevated aldosterone secretion and suppressed plasma renin activity used as } \\
\text { diagnostic criteria. JAMA. 1968; } 205 \text { (7): } 497-502\end{array}$ & observational study & 127 & 3 \\
\hline 53 & $\begin{array}{l}\text { Ogishima T, et al. Glucocorticoid-remediable aldosteronism in a large kindred - clinical spectrum and } \\
\text { diagnosis using a characteristic biochemical phenotype. Annals of Internal Medicine. 1992; } 116 \text { (10): } \\
813-820\end{array}$ & observational study & 124 & 5 \\
\hline 54 & $\begin{array}{l}\text { Conn JW, et al. Aldosterone synthase cytochrome-p- } 450 \text { expressed in the adrenals of patients with } \\
\text { primary aldosteronism. Journal of Biological Chemistry. 1991; } 266 \text { (17): 10731-10734 }\end{array}$ & basic science & 124 & 5 \\
\hline 55 & $\begin{array}{l}\text { Irony I, et al. Correctable subsets of primary aldosteronism: primary adrenal hyperplasia and renin } \\
\text { responsive adenoma. American Journal of Hypertension. 1990; } 3 \text { (7): 576-582 }\end{array}$ & observational study & 123 & 5 \\
\hline 56 & $\begin{array}{l}\text { Biglieri EG, et al. Significance of elevated levels of plasma 18-hydroxycorticosterone in patients with } \\
\text { primary aldosteronism. Journal of Clinical Endocrinology \& Metabolism. 1979; } 49 \text { (1): 87-91 }\end{array}$ & observational study & 122 & 3 \\
\hline 57 & $\begin{array}{l}\text { Rossi GP, et al. Excess aldosterone is associated with alterations of myocardial texture in primary } \\
\text { aldosteronism. Hypertension. } 2002 ; 40 \text { (1): } 23-27\end{array}$ & observational study & 117 & 8 \\
\hline 58 & $\begin{array}{l}\text { Weinberger MH, et al. The diagnosis of primary aldosteronism and separation of } 2 \text { major subtypes. } \\
\text { Archives of Internal Medicine. 1993; } 153 \text { (18): 2125-2129 }\end{array}$ & observational study & 116 & 5 \\
\hline 59 & $\begin{array}{l}\text { Biglieri EG, et al. In vivo and in vitro studies of adrenal secretions in cushings syndrome and primary } \\
\text { aldosteronism. Journal of Clinical Investigation. } 1963 ; 42 \text { (4): 516-524 }\end{array}$ & observational study & 115 & 2 \\
\hline 60 & $\begin{array}{l}\text { GeorgeJM, et al. The syndrome of primary aldosteronism. American Journal of Medicine. 1970; } 48 \text { (3): } \\
343-356\end{array}$ & observational study & 113 & 2 \\
\hline 61 & $\begin{array}{l}\text { Conn JW. Aldosteronism and hypertension: primary aldosteronism versus hypertensive disease with } \\
\text { secondary aldosteronism. Archives of Internal Medicine. } 1961 ; 107(6): 813-828\end{array}$ & review & 113 & 2 \\
\hline 62 & $\begin{array}{l}\text { Kem DC, et al. Circadian-rhythm of plasma aldosterone concentration in patients with primary } \\
\text { aldosteronism. Journal of Clinical Investigation. 1973; } 52 \text { (9): 2272-2277 }\end{array}$ & observational study & 112 & 3 \\
\hline 63 & $\begin{array}{l}\text { Jonsson JR, et al. A new genetic test for familial hyperaldosteronism type-i aids in the detection of curable } \\
\text { hypertension. Biochemical and Biophysical Research Communications. 1995; } 207 \text { (2): 565-571 }\end{array}$ & basic science & 111 & 5 \\
\hline 64 & $\begin{array}{l}\text { Young WF, et al. Primary aldosteronism - diagnostic evaluation. Endocrinology and Metabolism } \\
\text { Clinics of North America. 1988; } 17 \text { (2): 367-395 }\end{array}$ & review & 111 & 4 \\
\hline 65 & $\begin{array}{l}\text { Catena C, et al. Insulin sensitivity in patients with primary aldosteronism: a follow-up study. Journal of } \\
\text { Clinical Endocrinology \& Metabolism. 2006; } 91 \text { (9): } 3457-3463\end{array}$ & obser & 109 & 11 \\
\hline
\end{tabular}




\begin{tabular}{|c|c|c|c|c|}
\hline rank & article & study design & citations & $\begin{array}{l}\text { citation } \\
\text { density }\end{array}$ \\
\hline 66 & $\begin{array}{l}\text { Doppman JL, et al. Distinction between hyperaldosteronism - due to bilateral hyperplasia and unilateral } \\
\text { aldosteronoma - reliability of ct. Radiology. 1992; } 184 \text { (3): 677-682 }\end{array}$ & observational study & 107 & 4 \\
\hline 67 & $\begin{array}{l}\text { Schambelan M, et al. Circadian-rhythm and effect of posture on plasma aldosterone concentration in } \\
\text { primary aldosteronism. Journal of Clinical Endocrinology \& Metabolism. 1976; } 43 \text { (1): 115-131 }\end{array}$ & observational study & 107 & 3 \\
\hline 68 & $\begin{array}{l}\text { Gomezsanchez CE, et al. Elevated urinary excretion of 18-oxocortisol in glucocorticoid-suppressible } \\
\text { aldosteronism. Journal of Clinical Endocrinology \& Metabolism. 1984; } 59 \text { (5): 1022-1024 }\end{array}$ & basic science & 105 & 3 \\
\hline 69 & $\begin{array}{l}\text { Nishimura M, et al. Cardiovascular complications in patients with primary aldosteronism. American } \\
\text { Journal of Kidney Diseases. 1999; } 33 \text { (2): 261-266 }\end{array}$ & observational study & 104 & 6 \\
\hline 70 & $\begin{array}{l}\text { Hogan MJ, et al. Location of aldosterone-producing adenomas with i-131-19-iodocholesterol. New } \\
\text { England Journal of Medicine. 1976; } 294 \text { (8): 410-414 }\end{array}$ & observational study & 104 & 3 \\
\hline 71 & $\begin{array}{l}\text { Pascoe L, et al. Glucocorticoid-suppressible hyperaldosteronism and adrenal-tumors occurring in a } \\
\text { single french pedigree. Journal of Clinical Investigation. 1995; } 96 \text { (5): 2236-2246 }\end{array}$ & basic science & 102 & 5 \\
\hline 72 & $\begin{array}{l}\text { Davis WW, et al. Bilateral adrenal hyperplasia as a cause of primary aldosteronism with hypertension } \\
\text { hypokalemia and suppressed renin activity. American Journal of Medicine. 1967; } 42 \text { (4): 642-647 }\end{array}$ & observational study & 102 & 2 \\
\hline 73 & $\begin{array}{l}\text { Montori VM, et al. Use of plasma aldosterone concentration-to-plasma renin activity ratio as a } \\
\text { screening test for primary aldosteronism - a systematic review of the literature. Endocrinology and } \\
\text { Metabolism Clinics of North America. 2002; } 31 \text { (3): 619-632 }\end{array}$ & systematic review & 101 & 7 \\
\hline 74 & Gordon RD. Primary aldosteronism. Journal of Endocrinological Investigation. 1995; 18 (7): 495-511 & review & 100 & 5 \\
\hline 75 & $\begin{array}{l}\text { Yamaji T, et al. Plasma levels of atrial natriuretic peptide in primary aldosteronism and essential } \\
\text { hypertension. Journal of Clinical Endocrinology \& Metabolism. 1986; } 63 \text { (4): 815-818 }\end{array}$ & observational study & 100 & 3 \\
\hline 76 & $\begin{array}{l}\text { Davies LA, et al. Task channel deletion in mice causes primary hyperaldosteronism. PNAS. 2008; } 105 \\
\text { (6): 2203-2208 }\end{array}$ & basic science & 98 & 12 \\
\hline 77 & $\begin{array}{l}\text { Mulatero P, et al. Diagnosis of primary aldosteronism: from screening to subtype differentiation. Trends } \\
\text { in Endocrinology and Metabolism. 2005; } 16 \text { (3): 114-119 }\end{array}$ & review & 96 & 9 \\
\hline 78 & $\begin{array}{l}\text { Celen O, et al. Factors influencing outcome of surgery for primary aldosteronism. Archives of Surgery. } \\
\text { 1996; } 131 \text { (6): 646-650 }\end{array}$ & observational study & 95 & 5 \\
\hline 79 & $\begin{array}{l}\text { Lyons DF, et al. Single dose captopril as a diagnostic test for primary aldosteronism. Journal of Clinical } \\
\text { Endocrinology \& Metabolism. 1983; } 57 \text { (5): 892-896 }\end{array}$ & observational study & 94 & 3 \\
\hline 80 & $\begin{array}{l}\text { White EA, et al. Use of computed-tomography in diagnosing the cause of primary aldosteronism. New } \\
\text { England Journal of Medicine. 1980; } 303 \text { (26): 1503-1507 }\end{array}$ & observational study & 94 & 3 \\
\hline 81 & $\begin{array}{l}\text { Chu MD, et al. Isolation and identification of } 18 \text {-hydroxycortisol from the urine of patients with } \\
\text { primary aldosteronism. Journal of Biological Chemistry. 1982;257 (5): 2218-2224 }\end{array}$ & basic science & 93 & 3 \\
\hline 82 & $\begin{array}{l}\text { Phillips JL, et al. Predictive value of preoperative tests in discriminating bilateral adrenal hyperplasia } \\
\text { from an aldosterone-producing adrenal adenoma. Journal of Clinical Endocrinology \& Metabolism. } \\
\text { 2000; } 85 \text { (12): } 4526-4533\end{array}$ & observational study & 92 & 6 \\
\hline 83 & $\begin{array}{l}\text { Rovner DR, et al. Nature of renal escape from sodium-retaining effect of aldosterone in primary } \\
\text { aldosteronism and in normal subjects. Journal of Clinical Endocrinology \& Metabolism. 1965;25 (1): 53-64 }\end{array}$ & observational study & 92 & 2 \\
\hline 84 & $\begin{array}{l}\text { Strauch B, et al. Prevalence of primary hyperaldosteronism in moderate to severe hypertension in the } \\
\text { central europe region. Journal of Human Hypertension. 2003; } 17 \text { (5): } 349-352\end{array}$ & observational study & 91 & 7 \\
\hline 85 & $\begin{array}{l}\text { Holland OB, et al. Further evaluation of saline infusion for the diagnosis of primary aldosteronism. } \\
\text { Hypertension. 1984; } 6 \text { (5): 717-723 }\end{array}$ & observational study & 91 & 3 \\
\hline 86 & $\begin{array}{l}\text { Ferriss JB, et al. Clinical, biochemical and pathological features of low-renin (primary) } \\
\text { hyper-aldosteronism. American Heart Journal. 1978; } 95 \text { (3): } 375-388\end{array}$ & review & 91 & 2 \\
\hline 87 & Neville AM, et al. Pathology of primary aldosteronism. Cancer. 1966; 19 (12): 1854-1868 & observational study & 91 & 2 \\
\hline 88 & $\begin{array}{l}\text { Giacchetti G, et al. Aldosterone as a key mediator of the cardiometabolic syndrome in primary } \\
\text { aldosteronism: an observational study. Journal of Hypertension. } 2007 ; 25 \text { (1): 177-186 }\end{array}$ & observational study & 90 & 10 \\
\hline 89 & $\begin{array}{l}\text { Stowasser M, et al. Diagnosis and management of primary aldosteronism. Journal of the } \\
\text { Renin-Angiotensin-Aldosterone System. 2001; } 2 \text { (3): 156-169 }\end{array}$ & review & 90 & 6 \\
\hline 90 & $\begin{array}{l}\text { Lim PO, et al. A review of the medical treatment of primary aldosteronism. Journal of Hypertension. } \\
2001 ; 19 \text { (3): 353-361 }\end{array}$ & systematic review & 90 & 6 \\
\hline 91 & $\begin{array}{l}\text { Biglieri EG, et al. Postoperative studies of adrenal function in primary aldosteronism. Journal of } \\
\text { Clinical Endocrinology \& Metabolism. 1966; } 26 \text { (5): 553-558 }\end{array}$ & observational study & 90 & 2 \\
\hline 92 & $\begin{array}{l}\text { Cain JP, et al. The regulation of aldosterone secretion in primary aldosteronism. American Journal of } \\
\text { Medicine. 1972; } 53 \text { (5): 627-637 }\end{array}$ & observational study & 89 & 2 \\
\hline 93 & $\begin{array}{l}\text { Conn JW, et al. Preoperative diagnosis of primary aldosteronism - including a comparison of operative } \\
\text { findings and preoperative tumor localization by adrenal phlebography. Archives of Internal Medicine. } \\
\text { 1969; } 123 \text { (2): 113-123 }\end{array}$ & observational study & 89 & 2 \\
\hline 94 & $\begin{array}{l}\text { Jose A, et al. Plasma renin activity in diagnosis of primary aldosteronism - failure to distinguish } \\
\text { primary aldosteronism from essential hypertension. Archives of Internal Medicine. 1969; } 123 \text { (2): } \\
\text { 141-146 }\end{array}$ & observational study & 89 & 2 \\
\hline 95 & $\begin{array}{l}\text { Boulkroun S, et al. Prevalence, clinical, and molecular correlates of kcnj5 mutations in primary } \\
\text { aldosteronism. Hypertension. 2012; } 59 \text { (3): 592-598 }\end{array}$ & basic science & 88 & 22 \\
\hline 96 & $\begin{array}{l}\text { Kempers MJE, et al. Systematic review: diagnostic procedures to differentiate unilateral from bilateral } \\
\text { adrenal abnormality in primary aldosteronism. Annals of Internal Medicine. 2009; } 151 \text { (5): 329-337 }\end{array}$ & systematic Review & 88 & 13 \\
\hline 97 & $\begin{array}{l}\text { Rossi GP, et al. Primary aldosteronism: cardiovascular, renal and metabolic implications. Trends in } \\
\text { Endocrinology and Metabolism. 2008; } 19 \text { (3): 88-90 }\end{array}$ & review & 88 & 11 \\
\hline
\end{tabular}




\begin{tabular}{|c|c|c|c|c|}
\hline rank & article & study design & citations & $\begin{array}{l}\text { citation } \\
\text { density }\end{array}$ \\
\hline 98 & $\begin{array}{l}\text { Stowasser M, et al. Evidence for abnormal left ventricular structure and function in normotensive } \\
\text { individuals with familial hyperaldosteronism type I. Journal of Clinical Endocrinology \& Metabolism. } \\
\text { 2005; } 90 \text { (9): 5070-5076 }\end{array}$ & observational study & 88 & 8 \\
\hline 99 & $\begin{array}{l}\text { Takeda M, et al. Laparoscopic adrenalectomy for primary aldosteronism - report of initial } 10 \text { cases. } \\
\text { Surgery. } 1994 ; 115(5): 621-625\end{array}$ & observational study & 88 & 4 \\
\hline 100 & $\begin{array}{l}\text { Slaton PE, et al. Stimulation and suppression of aldosterone secretion in patients with an } \\
\text { aldosterone-producing adenoma. Journal of Clinical Endocrinology \& Metabolism. 1969; } 29 \text { (2): 239-250 }\end{array}$ & observational study & 88 & 2 \\
\hline
\end{tabular}

\subsection{Publication Year}

The retrieved articles were published between 1955 and 2012. The top 100 cited articles were grouped by decade of publication as shown in Figure 1. The decade with the highest number of published articles was the 2000s (35 articles), followed by the 1990s (22 articles).

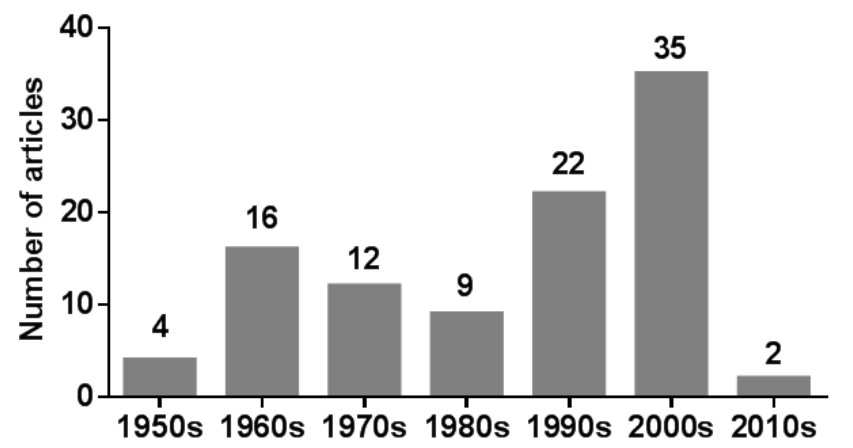

Figure 1. Distribution of top 100 cited articles in primary aldosteronism by decade.

\subsection{Study Design and Level of Evidence of the Top-cited Articles}

Observational studies had the most articles (70), followed by reviews (14), basic science (11), and systematic reviews (3) (Figure 2). Guideline and randomized controlled trial (RCT) were the least represented, each with only one article. In terms of level of evidence, levels $1 \mathrm{a}$ and $1 \mathrm{~b}$ each had a single article, whereas levels $2 a$. $2 b, 3 b, 4$ and 5 , were represented by $3,7,17$, 46 and 25 articles, respectively.

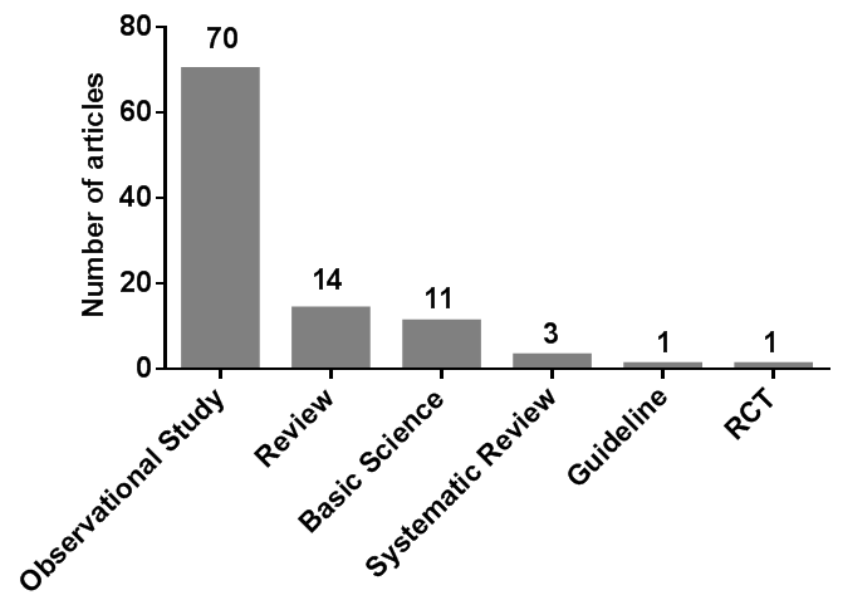

Figure 2. Distribution of top 100 cited articles in primary aldosteronism by study design.

\subsection{Authors, Countries, and Institutions of Origin}

We also analyzed the first author in each of the top 100 cited articles. Twelve authors published two or more of the most-cited articles (Table 2). Conn JW, the famous endocrinologist who authored ten classic articles and coined the term "primary aldosteronism" in 1955, was the leading author followed by Rossi GP and Young WF with seven and five classic articles, respectively.

Table 2. Most common first authors of the top 100 cited articles in primary aldosteronism.

\begin{tabular}{lll}
\hline Rank & Authors & Number of articles \\
\hline 1 & Conn JW & 10 \\
2 & Rossi GP & 7 \\
3 & Young WF & 5 \\
$4 \mathrm{a}$ & Biglieri EG & 3 \\
$4 \mathrm{~b}$ & Gordon RD & 3 \\
$4 \mathrm{c}$ & Lim PO & 3 \\
$4 \mathrm{~d}$ & Stowasser M & 3 \\
$5 \mathrm{a}$ & Catena C & 2 \\
$5 \mathrm{~b}$ & Ganguly A & 2 \\
$5 \mathrm{c}$ & Mulatero P & 2 \\
$5 \mathrm{~d}$ & Pascoe L & 2 \\
$5 \mathrm{e}$ & Weinberger MH & 2 \\
\hline
\end{tabular}

Table 3. Countries of origin of the top 100 cited articles in primary aldosteronism.

\begin{tabular}{lll}
\hline Rank & Country & Number of articles \\
\hline 1 & USA & 62 \\
2 & Italy & 16 \\
3 & Australia & 9 \\
4 & UK & 8 \\
5 & Japan & 6 \\
$6 \mathrm{a}$ & Chile & 3 \\
$6 \mathrm{~b}$ & France & 3 \\
7 & Germany & 2 \\
$8 \mathrm{a}$ & Argentina & 1 \\
$8 \mathrm{~b}$ & Brazil & 1 \\
$8 \mathrm{c}$ & Czech Republic & 1 \\
$8 \mathrm{~d}$ & Greece & 1 \\
$8 \mathrm{e}$ & Netherlands & 1 \\
$8 \mathrm{f}$ & New Zealand & 1 \\
$8 \mathrm{~g}$ & Singapore & 1 \\
$8 \mathrm{~h}$ & Sweden & 1 \\
\hline
\end{tabular}

The top 100 cited articles originated from 16 countries (Table 3). Countries with the most articles were the United States of America (62), Italy (16), Australia (9), the United Kingdom (8), and Japan (6). Only 12 articles were completed through multinational collaborations, whereas the authors of each of the 88 articles were all from the same country. 
Table 4. Institutions of origin with 3 or more top 100 cited articles in primary aldosteronism.

\begin{tabular}{llll}
\hline Rank & Institution & $\begin{array}{l}\text { Number of } \\
\text { articles }\end{array}$ & Country \\
\hline $1 \mathrm{a}$ & University of Michigan & 11 & USA \\
$1 \mathrm{~b}$ & University of Padua & 11 & Italy \\
2 & Mayo Clinic & 10 & USA \\
3 & University of California & 8 & USA \\
4 & Greenslopes Hospital & 6 & Australia \\
$5 \mathrm{a}$ & Indiana University & 4 & USA \\
$5 \mathrm{~b}$ & University of Texas & 4 & USA \\
$5 \mathrm{c}$ & University of Turin & 4 & Italy \\
$5 \mathrm{~d}$ & University of Udine & 4 & Italy \\
$6 \mathrm{a}$ & Catholic University of Chile & 3 & Chile \\
$6 \mathrm{~b}$ & Cornell University & 3 & USA \\
$6 \mathrm{c}$ & Harvard University & 3 & USA \\
$6 \mathrm{~d}$ & Howard Hughes Medical Institute & 3 & USA \\
$6 \mathrm{e}$ & Marche Polytechnic University & 3 & Italy \\
$6 \mathrm{f}$ & National Cancer Institute & 3 & USA \\
$6 \mathrm{~g}$ & University of Dundee & 3 & UK \\
$6 \mathrm{~h}$ & University of Queensland & 3 & Australia \\
\hline
\end{tabular}

Seventeen institutions published three or more of the top 100 cited articles (Table 4). Out of the 17, nine (53\%) institutions are located in the United States, whereas the other eight (47\%) are from various countries: four institutions from Italy, two from Australia, and one each from the UK and Chile. The institutions with the highest number of articles were University of Michigan and University of Padua ( $\mathrm{n}=11$ each), followed by Mayo Clinic $(n=10)$ and University of California $(n=8)$.

\subsection{Journals}

The top 100 cited articles were published in 37 journals (Table 5). The majority of the articles were published in the Journal of Clinical Endocrinology and Metabolism (n=19), Hypertension ( $\mathrm{n}=9)$, Annals of Internal Medicine $(\mathrm{n}=6)$, Archives of Internal Medicine $(\mathrm{n}=6)$, American Journal of Medicine ( $\mathrm{n}=5)$, and Journal of the American Medical Association (JAMA) $(\mathrm{n}=4)$. The majority of the articles $(42 \%$, 42 articles) were published in the leading journals in endocriminology or hypertension, while $36(36 \%)$ were published in the top medical journals. There was no correlation between the impact factor of a journal and the number of the top 100 cited articles it published $(\mathrm{r}=0.28$, $P>0.05)$.

Table 5. Journals in which the top 100 most cited articles were published.

\begin{tabular}{|c|c|c|c|}
\hline Rank & Journals & Number of articles & Impact factor (2016) \\
\hline 1 & Journal of Clinical Endocrinology Metabolism & 19 & 5.531 \\
\hline 2 & Hypertension & 9 & 6.294 \\
\hline $3 a$ & Annals of Internal Medicine & 6 & 16.440 \\
\hline $3 b$ & Archives of Internal Medicine & 6 & 14 \\
\hline $4 \mathrm{a}$ & American Journal of Medicine & 5 & 5.610 \\
\hline $4 b$ & The Journal of the American Medical Association (JAMA) & 5 & 59.558 \\
\hline 5 & New England Journal of Medicine & 4 & 37.684 \\
\hline $6 b$ & Journal of Hypertension & 3 & 5.062 \\
\hline $7 \mathrm{a}$ & American Journal of Kidney Diseases & 2 & 6.269 \\
\hline $7 b$ & Biochemical and Biophysical Research Communications & 2 & 2.371 \\
\hline $7 \mathrm{c}$ & Clinical and Experimental Pharmacology and Physiology & 2 & 2.004 \\
\hline $7 \mathrm{~d}$ & Endocrinology and Metabolism Clinics of North America & 2 & 3.305 \\
\hline $7 e$ & Journal of Biological Chemistry & 2 & 4.258 \\
\hline $7 f$ & Journal of Human Hypertension & 2 & 2.833 \\
\hline $7 \mathrm{~h}$ & Journal of The American College of Cardiology & 2 & 17.759 \\
\hline $7 \mathrm{i}$ & Lancet & 2 & 44.002 \\
\hline $7 \mathrm{j}$ & Proceedings of the National Academy of Sciences (PNAS) & 2 & 9.423 \\
\hline $7 \mathrm{k}$ & Surgery & 2 & 3.309 \\
\hline 71 & Trends In Endocrinology and Metabolism & 2 & 8.964 \\
\hline $8 \mathrm{a}$ & American Heart Journal & 1 & 4.332 \\
\hline $8 b$ & American Journal of Hypertension & 1 & 3.182 \\
\hline $8 \mathrm{c}$ & American Journal of Surgery & 1 & 2.403 \\
\hline $8 \mathrm{~d}$ & Archives of Surgery & 1 & 5.661 \\
\hline $8 \mathrm{e}$ & Australian and New Zealand Journal of Medicine & 1 & \\
\hline $8 \mathrm{f}$ & Cancer & 1 & 5.649 \\
\hline $8 \mathrm{~g}$ & Circulation & 1 & 17.047 \\
\hline $8 \mathrm{~h}$ & Clinical Endocrinology & 1 & 3.487 \\
\hline $8 \mathrm{i}$ & Endocrinology & 1 & 4.159 \\
\hline $8 \mathrm{j}$ & Journal of Endocrinological Investigation & 1 & 1.994 \\
\hline $8 \mathrm{~m}$ & Nature & 1 & 38.138 \\
\hline $8 n$ & Quarterly Journal of Medicine & 1 & \\
\hline 80 & Radiology & 1 & 6.798 \\
\hline $8 \mathrm{p}$ & Science & 1 & 34.661 \\
\hline
\end{tabular}




\subsection{Investigation of Possible Factors Influencing Citations}

To determine the factors influencing the number of citations of the most-cited articles, we investigated the relationships between the number of citations and the number of years since publication, the number of authors, the number of institutions
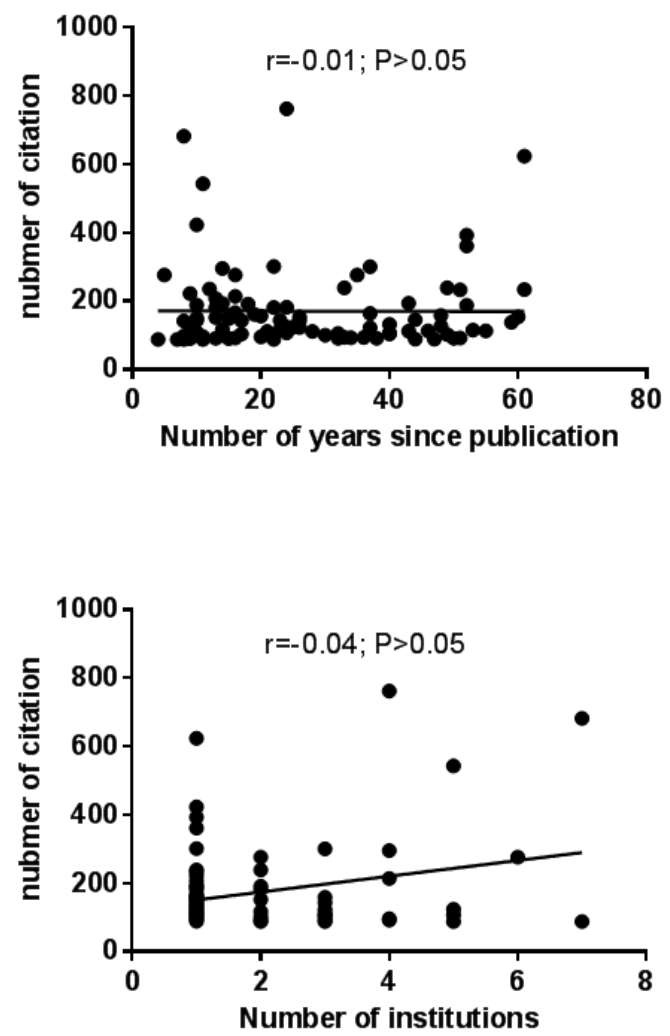

or the number of countries involved. There was no correlation between the number of citations and the number of years since publication $(r=-0.01, P=0.96)$, the number of authors $(r=0.05$, $P=0.65)$, the number of institutions $(r=-0.04, P=0.71)$ or the number of countries involved $(r=-0.05, P=0.59)$ (Figure 3 ).
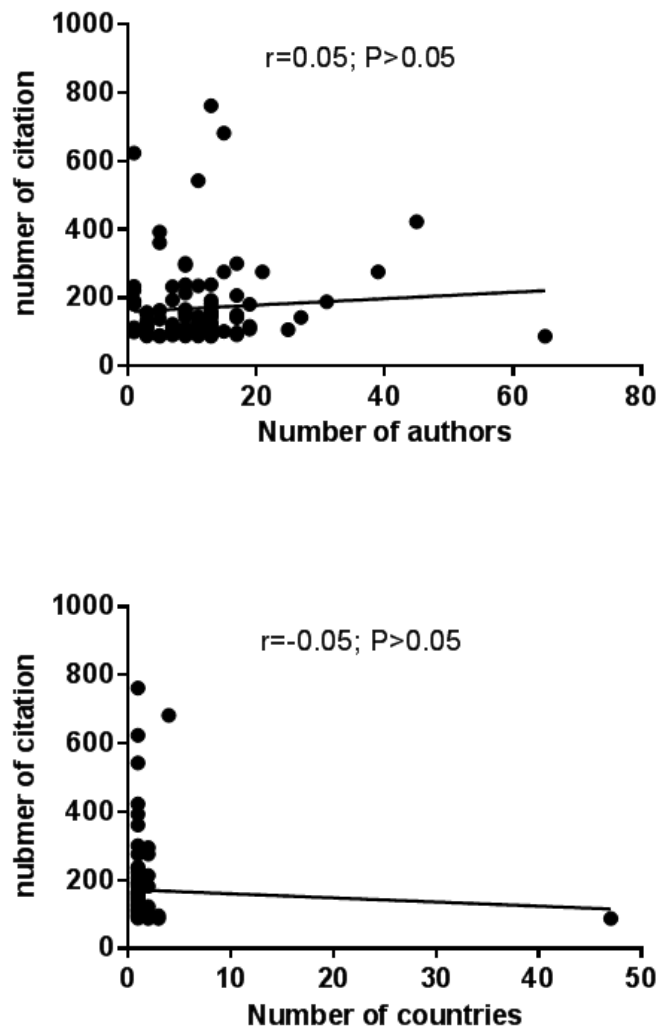

Figure 3. Correlations between the number of citations and the number of years since publication (A), the number of authors (B), the number of institutions (C) or the number of countries involved (D).

\section{Discussion}

In this study, we used bibliometric method to identify and characterize the top 100 cited articles in the field of primary aldosteronism. Identifying the top 100 cited publications is useful for the following reasons. Firstly, it highlights the landmark articles in the development of primary aldosteronism. Furthermore, it enables researchers or clinicians to get essential information about authors and institutions that have greatly contributed to these milestones and have subsequently steered the primary aldosteronism field. Lastly, knowing and understanding the key features of the most-cited articles will aid young researchers in publishing effectively [19].

The top 100 cited articles on primary aldosteronism were cited 88-762 times, which is remarkably lower than that of classic articles in other medical fields, such as hypertension (582-7248), diabetes (1121-10292), and tuberculosis (366-4443) [10-12]. Citations varied by specialty and were likely to be influenced by the number of researchers active in a specific medical field [14]. For example, hypertension, diabetes, and tuberculosis are the most common diseases and continue to increase rapidly worldwide. Consequently, more researchers are focusing on these areas rather than primary aldosteronism.

A proportion of the 100 most-cited articles in the field of primary aldosteronism were published recently, with 37 articles being published after 2000, which was similar to the findings of some bibliometric analyses [14, 20]. However, previous bibliometric-based studies indicated that articles might take at least 15 years to achieve a peak in citations [13, 21]. This disparity could be attributed to a number of factors. First, similar to digestive diseases, more articles emerged in the past 15 years and researchers in the field of primary aldosteronism tend to cite the most recent studies [14]. Furthermore, the number of citations showed no correlation with the number of years since publication. Finally, the time period varies with specialty since different journals and fields have diverse citation half-lives [22].

Although RCTs provided the highest-quality evidence for most clinical problems, only one RCT (level 1b) was found among the 100 most-cited articles in the field of primary aldosteronism. This is contrary to most other specialties, such as hypertension $(\mathrm{n}=24)$ and diabetes $(\mathrm{n}=29) \quad[11,12]$. 
Consequently, further research is needed to provide more high-level evidence of clinical trials. Several possible reasons can explain the lack of RCTs in primary aldosteronism. First, it is difficult for primary aldosteronism to enroll abundant patients in comparison with hypertension and diabetes. Furthermore, RCTs are extremely expensive and time-consuming. Consequently, we discovered that observational studies accounted for the majority of the most-cited articles in the field of primary aldosteronism, implying that novel concepts were initially published as observational studies and could still be of interest to the scientific community.

Our study also found that the United States produced the majority of the top 100 cited articles. In addition, nine of the 17 leading institutions in primary aldosteronism articles were based in the United States. These results were similar to those reported in a variety of medical fields regarding to the origin of 100 most-cited articles [11, 12, 23, 24], demonstrating that USA was far ahead in medical research due to its large number of researchers and plentiful funding. Furthermore, American authors prefer to cite local articles, and American reviewers favor articles from their own country [21, 25, 26].

This study revealed that the top 100 cited articles were published in 37 journals. Forty-two articles (42\%) were published in the top journals in endocriminology or hypertension. According to Bradford's law, citations are mostly obtained from a few core journals in the specialized field, whereas articles published in non-core journals have significantly fewer citations [27]. Thus, most of the top-cited articles appear in a few major, specialized medical journals. In this study, two specialized journals: Journal of Clinical Endocrinology Metabolism and Hypertension, published the highest number $(n=28)$ of the 100 most-cited articles. However, many top-cited articles on primary aldosteronism were published in general medical journals with high impact factors, such as Annals of Internal Medicine $(\mathrm{n}=6)$, Archives of Internal Medicine $(\mathrm{n}=6)$, and JAMA $(\mathrm{n}=5)$.

The impact factor of a journal has been shown to be the strongest determinant of citations, and most of the top-cited articles were published in journals with high impact factors [28]. However, in line with some of the previous bibliometric analyses [29, 30], we found no significant correlation between the impact factor of a journal and the number of the top 100 cited articles in the field of primary aldosteronism. Nevertheless, certain bibliometric-based studies contradicted the aforementioned conclusions, suggesting that the tendency for top-cited articles to be published in general or specialized journals varies across different medical fields [20, 24]. These findings indicated the need for more accurate measures to assess the significance of specific research papers.

There were some limitations in this study. First, we only used a single medical database, Science Citation Index Expanded (SCIE). It is worth noting that SCIE did not index all journals at the time of the study, and certain journals that may be indexed in Google Scholar or Scopus databases were overlooked. Therefore, our results differed significantly from those obtained using various databases [31-33]. However, it is acceptable to use a single medical database to identify top-cited medical research articles-many published bibliometric analyses have used the SCIE database for this purpose [11, 32-35]. Furthermore, to prevent the "obliteration by incorporation" effect which has been demonstrated in the literature of other medical fields, we created the list of the top 100 cited articles based on the absolute amount of citations that articles received. This could preferentially favor older articles that have accumulated numerous citations over time $[20,24,36,37]$. Other potential factors that affect citations such as journal and author self-citation, citations in textbooks, conferences and web-based literatures, omission bias may not be accurately determined $[21,38]$.

\section{Conclusion}

Despite the above mentioned shortcomings, this study showed the characteristics of the top-cited articles in the field of primary aldosteronism. The top-cited articles were mainly observational studies, and high-quality evidence-based articles were still rare. The majority of the top-cited articles were published in the Journal of Clinical Endocrinology and Metabolism and Hypertension, and were from American institutions. Our findings provide insight into the history and evolution of primary aldosteronism, and a foundation for future research. Given that only a single RCT article was identified in this study, more RCTs on the diagnosis and treatment of primary aldosteronism should be conducted in future to improve clinical practice. There were no Chinese researchers nor institution among the 100 top-cited articles. Therefore, Chinese researchers should publish high-impact papers to guide further study in this field.

\section{Competing Interests}

The authors declare that they have no competing interests.

\section{References}

[1] Funder JW, Carey RM, Fardella C, et al. Case detection, diagnosis, and treatment of patients with primary aldosteronism: an endocrine society clinical practice guideline. The Journal of clinical endocrinology and metabolism 2008; 93: 3266-81.

[2] Nishimura M, Uzu T, Fujii $T$, et al. Cardiovascular complications in patients with primary aldosteronism. American journal of kidney diseases: the official journal of the National Kidney Foundation 1999; 33: 261-6.

[3] Savard S, Amar L, Plouin PF, et al. Cardiovascular complications associated with primary aldosteronism: a controlled cross-sectional study. Hypertension 2013; 62: 331-6.

[4] Moed HF. The impact-factors debate: the ISI's uses and limits. Nature 2002; 415: 731-2.

[5] Garfield E. Citation analysis as a tool in journal evaluation. Science (New York, NY) 1972; 178: 471-9. 
[6] Nason GJ, Tareen F, Mortell A. The top 100 cited articles in urology: An update. Canadian Urological Association journal = Journal de l'Association des urologues du Canada 2013; 7: E16-24.

[7] Seriwala HM, Khan MS, Shuaib W, et al. Bibliometric analysis of the top 50 cited respiratory articles. Expert review of respiratory medicine 2015; 9: 817-24.

[8] Chuang KY, Ho YS. A bibliometric analysis on top-cited articles in pain research. Pain medicine (Malden, Mass) 2014; 15: 732-44.

[9] O'Kelly F, Nason GJ, McLoughlin LC, et al. A comparative bibliometric analysis of the top 150 cited papers in hypospadiology (1945-2013). Journal of pediatric urology 2015; 11: 85 e1- e11.

[10] Chen LM, Liu YQ, Shen JN, et al. The 100 top-cited tuberculosis research studies. The international journal of tuberculosis and lung disease: the official journal of the International Union against Tuberculosis and Lung Disease 2015; 19: 717-22.

[11] Oh YS, Galis ZS. Anatomy of success: the top 100 cited scientific reports focused on hypertension research. Hypertension 2014; 63: 641-7.

[12] Zhao X, Guo L, Lin Y, et al. The top 100 most cited scientific reports focused on diabetes research. Acta diabetologica 2016; 53: $13-26$

[13] Hui J, Han Z, Geng G, et al. The 100 top-cited articles in orthodontics from 1975 to 2011. The Angle orthodontist 2013; 83: 491-9.

[14] Tang X, Gong W, Yuan F, et al. Top-cited articles in digestive system disease from 1950 to 2013. Journal of gastroenterology and hepatology 2016; 31: 107-11.

[15] Stern RS, Arndt KA. Top cited authors in dermatology: a citation study from 24 journals: 1982-1996. Archives of dermatology 1999; 135: 299-302.

[16] Zhang Y, Huang J, Du L. The top-cited systematic reviews/meta-analyses in tuberculosis research: A PRISMA-compliant systematic literature review and bibliometric analysis. Medicine 2017; 96: e4822.

[17] Lifton RP, Dluhy RG, Powers M, et al. A chimaeric 11 beta-hydroxylase/aldosterone synthase gene causes glucocorticoid-remediable aldosteronism and human hypertension. Nature 1992; 355: 262-5.

[18] Conn JW. Presidential address. I. Painting background. II. Primary aldosteronism, a new clinical syndrome. The Journal of laboratory and clinical medicine $1955 ; 45: 3-17$.

[19] Bayram B, Limon O, Limon G, et al. Bibliometric analysis of top 100 most-cited clinical studies on ultrasound in the Emergency Department. The American journal of emergency medicine 2016.

[20] Shuaib W, Khan MS, Shahid H, et al. Bibliometric analysis of the top 100 cited cardiovascular articles. The American journal of cardiology 2015; 115: 972-81.

[21] Pagni M, Khan NR, Cohen HL, et al. Highly cited works in radiology: the top 100 cited articles in radiologic journals. Academic radiology 2014; 21: 1056-66.
[22] Marx W, Schier H, Wanitschek M. Citation analysis using online databases: Feasibilities and shortcomings. Scientometrics 2001; 52: 59-82.

[23] Fardi A, Kodonas K, Gogos C, et al. Top-cited articles in endodontic journals. Journal of endodontics 2011; 37: 1183-90.

[24] Shuaib W, Acevedo JN, Khan MS, et al. The top 100 cited articles published in emergency medicine journals. The American journal of emergency medicine 2015; 33: 1066-71.

[25] Narin F, Hamilton KS. Bibliometric performance measures. Scientometrics 1996; 36: 293-310.

[26] Link AM. US and non-US submissions: an analysis of reviewer bias. Jama 1998; 280: 246-7.

[27] Brookes BC. Bradford's law and the bibliography of science. Nature 1969; 224: 953-6.

[28] Callaham M, Wears RL, Weber E. Journal prestige, publication bias, and other characteristics associated with citation of published studies in peer-reviewed journals. Jama 2002; 287: 2847-50.

[29] Huo YQ, Pan XH, Li QB, et al. Fifty top-cited classic papers in orthopedic elbow surgery: A bibliometric analysis. International journal of surgery (London, England) 2015; 18: 28-33.

[30] Long X, Huang JZ, Ho YS. A historical review of classic articles in surgery field. American journal of surgery 2014; 208 $841-9$

[31] Bakkalbasi N, Bauer K, Glover J, et al. Three options for citation tracking: Google Scholar, Scopus and Web of Science. Biomedical digital libraries 2006; 3: 7 .

[32] Kulkarni AV, Aziz B, Shams I, et al. Comparisons of citations in Web of Science, Scopus, and Google Scholar for articles published in general medical journals. Jama 2009; 302: 1092-6.

[33] Falagas ME, Pitsouni EI, Malietzis GA, et al. Comparison of PubMed, Scopus, Web of Science, and Google Scholar: strengths and weaknesses. FASEB journal: official publication of the Federation of American Societies for Experimental Biology 2008; 22: 338-42.

[34] Azer SA, Azer S. Bibliometric analysis of the top-cited gastroenterology and hepatology articles. BMJ open 2016; 6: e009889.

[35] Zhang TS, Qin HL, Wang T, et al. Bibliometric analysis of top 100 cited articles in nonalcoholic fatty liver disease research. World journal of hepatology 2016; 8: 1478-88.

[36] Garfield E. 100 citation classics from the Journal of the American Medical Association. Jama 1987; 257: 52-9.

[37] Ahmad SS, Evangelopoulos DS, Abbasian M, et al. The hundred most-cited publications in orthopaedic knee research. The Journal of bone and joint surgery American volume 2014; 96: e190.

[38] Dumont JE. The bias of citations. Trends in biochemical sciences $1989 ; 14: 327-8$. 